\title{
Analysis of Crude Oil Price and Household Income in the State of Louisiana
}

\author{
Matthew Nga Uwakonye ${ }^{1}$, Gbolahan S. Osho ${ }^{2}$, Michael O. Adams ${ }^{3} \&$ Mahmoud Haj $^{1}$ \\ ${ }^{1}$ Grambling State University, USA \\ ${ }^{2}$ Prairie View A\&M University, USA \\ ${ }^{3}$ Texas Southern University, USA \\ Correspondence: Gbolahan S. Osho, Prairie View A\&M University, USA.
}

Received: December 25, 2020

Accepted: January 8, 2021

Online Published: March 17, 2021

doi:10.20849/iref.v4i1.838

URL: https://doi.org/10.20849/iref.v4i1.838

\begin{abstract}
A large part of determining gas price rests on the price paid for crude oil. There are several variables that can affect gas prices such as global and domestic demand and production supply, unpredictability in the Middle East, fluctuating weak United States dollar value, natural disasters, and household income. Some explanations are provided about some of the previously mentioned variables, but the focus of analysis is Louisiana crude oil price as it relates to household income. The method that was used in this current research is the regression model and the estimated linear regression equation least square method. A scatter plot is provided to display the relationship between variables. A chart that shows historical data of crude oil prices and a correlation of events as they relate to the rise or fall of oil price level is also provided. The multivariate correlation matrix shows that some variables are significant at $p$-value of 0.05 . The largest values indicated that the crude oil price per barrel was strongly positive $(r=0.9530)$ linked with Louisiana gas price while Louisiana median household income $(r=0.0898)$, unemployment rate in Louisiana $(r=0.3398)$. This paper evaluates crude oil price as a dependent variable and how it relates to major independent variables using a general linear regression. The result shows that a high unemployment rate in Louisiana lowers the Louisiana gas price and therefore inhibits oil and gas market. it is highly recommended that the U.S. could continue to increase drilling activities in the state of Louisiana all it wants but it is hard to expect greater domestic production to move gas prices by more than two percentage points in the next few years.
\end{abstract}

Keywords: Louisiana, crude oil price, median household income, unemployment rate

\section{Introduction}

Louisiana oil production comes from either onshore or offshore drilling which includes the outer continental shelf. At the end of the President George Bush's first year in office the oil production in Louisiana for the year of 2000 was $584,800,829$ barrels at an average price of $\$ 28.16$ per barrel. By the end of his Bush's second term for the year of 2008; 458,246,396 barrels were produced at an average price of $\$ 100.14$ per barrel. Oil production for the first year of the President Barrack Obama administration was 595,177,509 barrels at a price of $\$ 58.41$ per barrel for the year of 2009. Even though the production totals are not totaled for this current year there seems to be somewhat of a trend during both presidencies of having a surge in prices. 

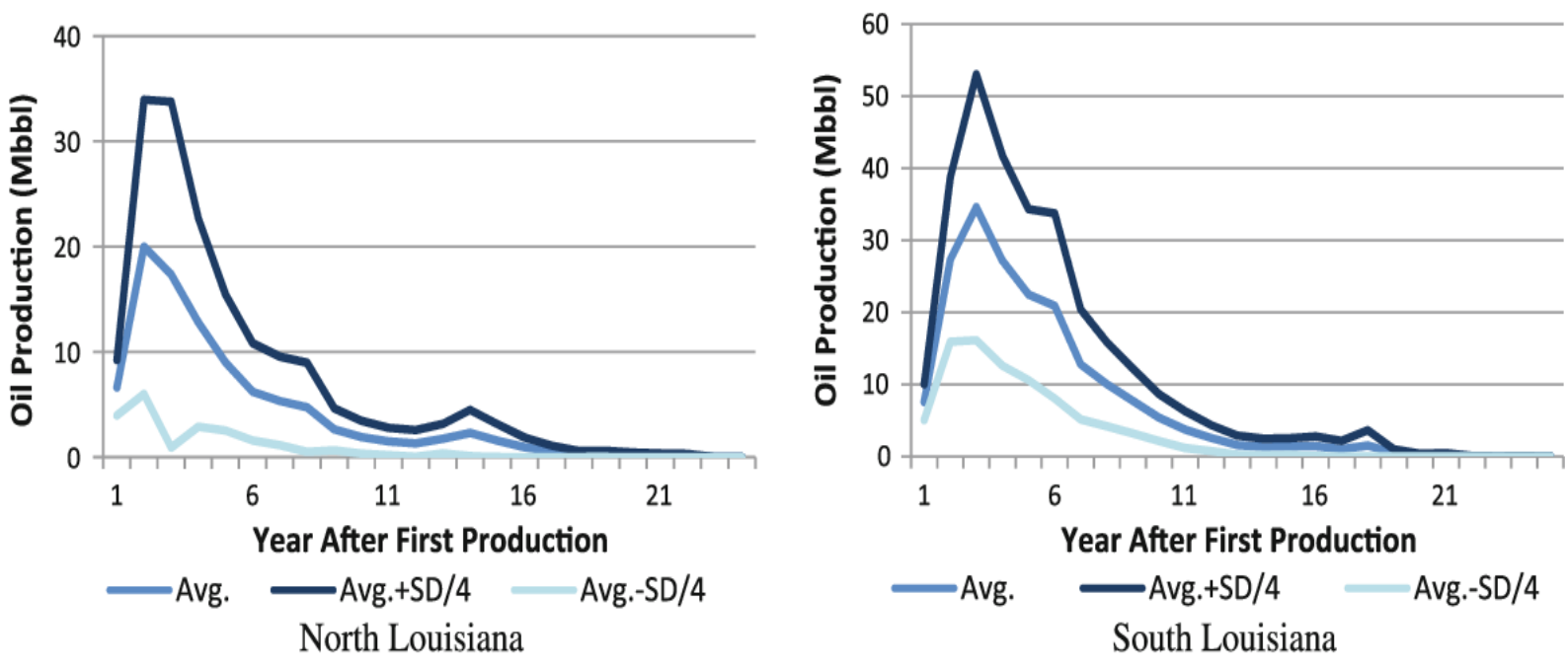

Figure 1. Average oil production profiles in North and South Louisiana

Reservoir production analysts found that oil and gas companies exhibit monopoly power in summertime as a result of environmental directives and policies. Moderately than have an only one summer blend, each key city has an exclusive preparation that is designed to alleviating its separate environmental pollution challenges. These exclusive blends make it problematic to transport gasoline from excess to shortage cities that curbs price peak and fluctuation. Subsequently, oil and gas companies display more regional market power during the summertime than another during the year. Lastly, statistics show that gas prices are higher in the summer because of numerous of reasons from family vacations to oil refinery profits. However, gas prices should be lower during the summer and can be higher during the winter. During the winter or during the holidays as a result of people seem to travel more, in the winter months everybody orders or wants their special someone gift delivered on time postal trucks are using a lot more fuel to delivery your package on time.

An increase or reduction in production could come from several factors such as supply, demand, inflation, natural disasters, war, or a combination of these factors. During the summer months June through August, demand is usually at its peak for the year. This is the time where people take vacations, little league sports activities and other seasonal work is at its peak such as lawn care services. The weak dollar is also a factor, which makes our imports less attractive to outside countries which mean that we will depend more on exports which will make oil become more expensive. For example, the three major countries mostly responsible for the increase in fuel prices due to their increased demand are India, China and Brazil combined with the decrease in production in other countries such as Middle East, Libya and Saudi.

The BP oil spill in 2010 played a significant role in production along with hurricanes that paths included coming thru the Gulf of Mexico. Which in turn decreases production by shutting down oil rigs and it has an inverse effect on prices. From 2010 to 2011 the price per barrel increased by an estimate of $\$ 25$. Total oil production and average price per barrel were the highest during the Bush administration. It is very annoying to hear so many uniformed Americans blame the president for rising gas prices. The fact is that they are set by exchanges made around the world. People sound ignorant and uninformed when blaming President Obama for higher gas prices. The reason it is up from a few years ago is because crude oil prices are up, due to the rise of demand from rapidly developing economies around the world. Demand is high; therefore, the product can be sold at higher a price which follows a simple economics theory. 


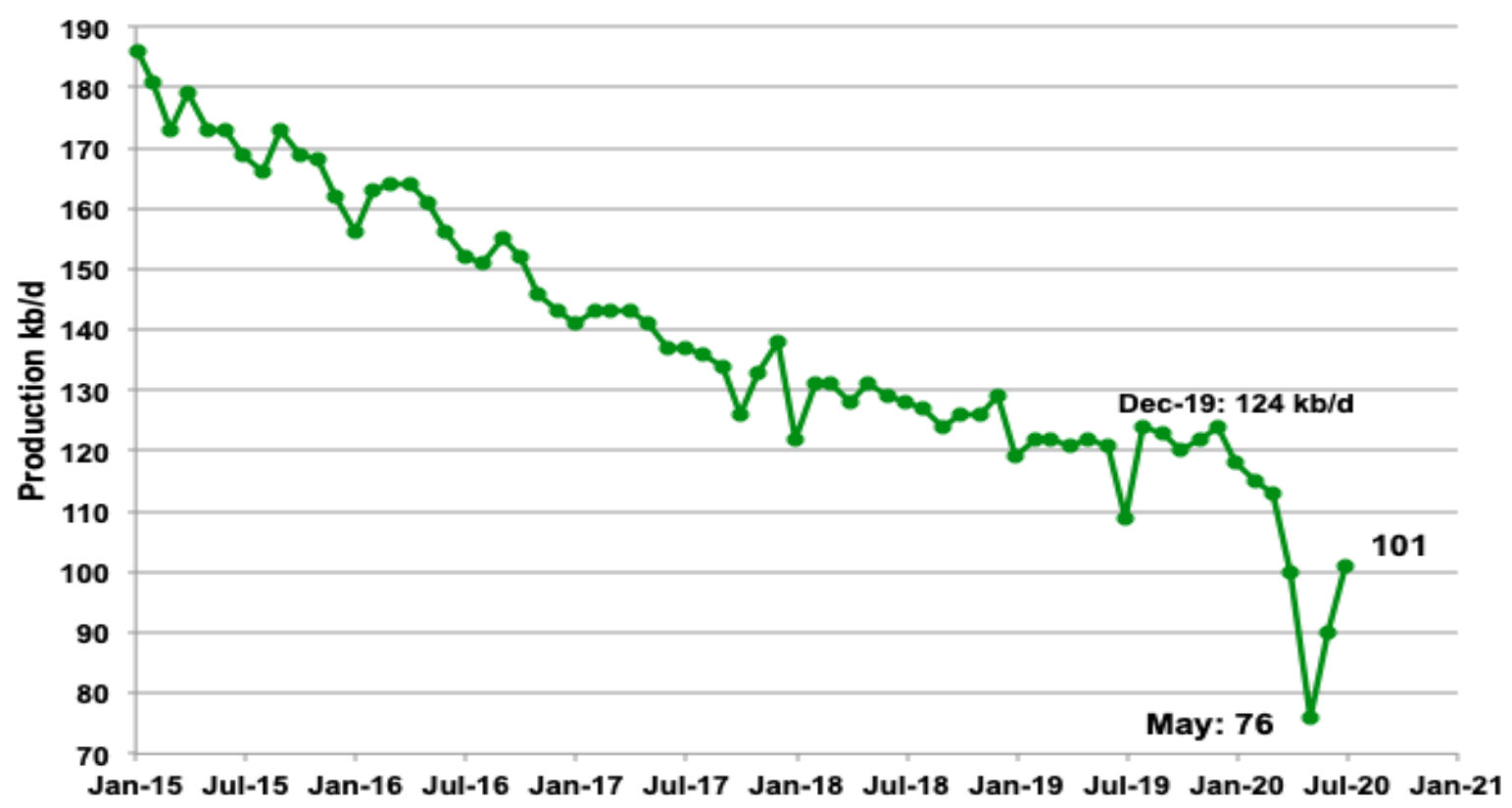

Figure 2. Louisiana production 2015-2020

Tactlessly, a large part of determining oil and gas price rests on the price paid for crude oil. Similarly prices of other commodities, the price of crude oil displays extensive price fluctuations during scarcity and also during excess surplus. The oil and gas price fluctuate range over more than a few years retorting to variations in demand and supply from both OPEC and non-OPEC. There are several variables that can affect gas prices such as global/domestic supply and demand, uncertainty in the Middle East, fluctuating weak United States dollar value, natural disasters or weather conditions requiring expensive additives, offshore drilling arguments, the cost of crude oil, and household income. From Figure 2, Louisiana's current production has reversed the stable decrease since first quarter of 2020. By the end of third quarter of 2020, output recovered by $11 \mathrm{~kb} / \mathrm{d}$ to $101 \mathrm{~kb} / \mathrm{d}$. By the beginning of first quarter of 2020 , the average rig count was 22 . By the end of the first month, Louisiana's rig count improved to an increase by 13 from to 9 by the third quarter.

Although some explanation will be provided about some of the previously mentioned variables, the focus of analysis will be Louisiana crude oil price as it relates to household income specific to the state of Louisiana. Data will be input into a table and calculated. A scatterplot will be provided to display the relationship between variables.

Table 1. Ranking: United Sates oil production by oil states

\begin{tabular}{llllll}
\hline & & & & Monthly & Yearly \\
Change & Change \\
\hline US Total & 11,823 & 10,446 & 10,984 & 538 & -839 \\
Texas & 5,080 & 872 & 4,735 & 103 & -345 \\
North Dakota & 1,416 & 872 & 1,029 & 157 & -387 \\
New Mexico & 892 & 946 & 988 & 42 & 96 \\
Oklahoma & 560 & 461 & 482 & 21 & -78 \\
Colorado & 509 & 450 & 450 & 0 & -59 \\
Alaska & 448 & 361 & 444 & 83 & -4 \\
California & 442 & 392 & 388 & -4 & -54 \\
Wyoming & 282 & 222 & 237 & 15 & -45 \\
Louisiana & 109 & 90 & 101 & 11 & -8 \\
Utah & 101 & 78 & 84 & 6 & -17 \\
Total & 9,839 & 8,504 & 8938 & 433 & -901 \\
\hline
\end{tabular}


A chart is also included which shows historical data of crude oil prices and a correlation of events as they relate to the rise or fall of oil price levels. The objective of this document is to determine the relationship between two variables that affect gas prices, a dependent crude oil price and an independent variable (household income), through regression analysis using the linear regression model. Upon completion, the outcome will attempt to provide insights about the association between these variables.

The household median annual income in Louisiana is roughly about $\$ 47,905$ compare to the United States median annual income roughly about $\$ 61,937$. In contrast to a median income of $\$ 46,145$ in 2017 , this signifies about a $4 \%$ annual growth. Figure 3: Median Household Income Increase Slightly in Louisiana and Nation when inflation adjusted value 2018 dollars shows that the median household income in Louisiana is $\$ 51,073$. While real median annual income in Louisiana is roughly about maxed \$52,057 in 2008

Current as of 2018, the highest household median annual income in Louisiana is roughly of $\$ 47,543$ in 2018. While the real median household income for Louisiana has increased by approximately $7 \%$.

\section{- Louisiana = U.S.}

\section{$\$ 80,000$}

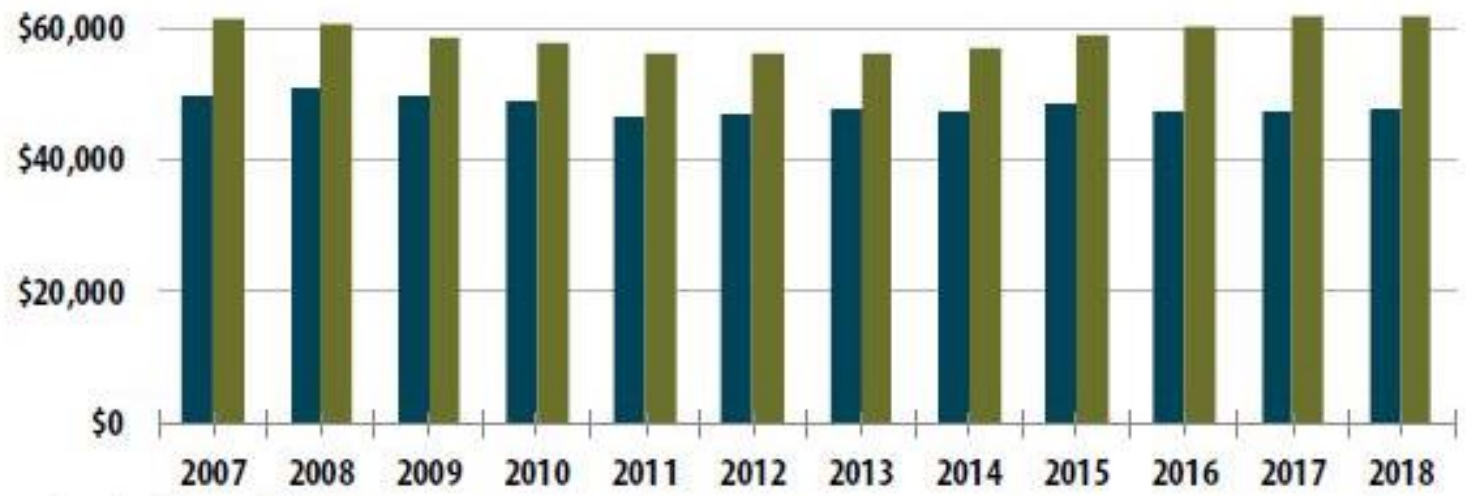

Figure 3. Median household income increase slightly in Louisiana and Nation

(Inflation Adjusted Value 2018 Dollars)

Source: American Community Survey

1-Year Estimates (B19013); Bureau of Labor Statistics, CPI-U-RS

\section{Model Specification}

The method that was used in this current research is the regression model and the estimated linear regression equation least square method. The available data were collected from the U.S. Energy Information Administration (EIA), The U.S. Census Bureau, and Louisiana Workforce Commission. Data set including crude oil price per barrel, Louisiana gas price, Louisiana median household income unemployment rate in Louisiana.

Regression analysis comprises a dependent variable and multiple independent variables where the relationship among the variables is estimated with a linear approximation. For this current study, regression studies continue to be an important part of scientific study today. With today's dismal state of the economy and a high unemployment rate, household income is lower which results in lower consumer spending power. One of the biggest complaints among all Americans recently has been high gas prices. The regression chart contains data used to analyze the relationship between independent variable, Louisiana median household income, and dependent variable, the price of crude oil in Louisiana. Mathematical formulas have been programmed into the spreadsheet and computations performed on the data inse1ted. The Least Square Method is used to find the estimated regression equation. 


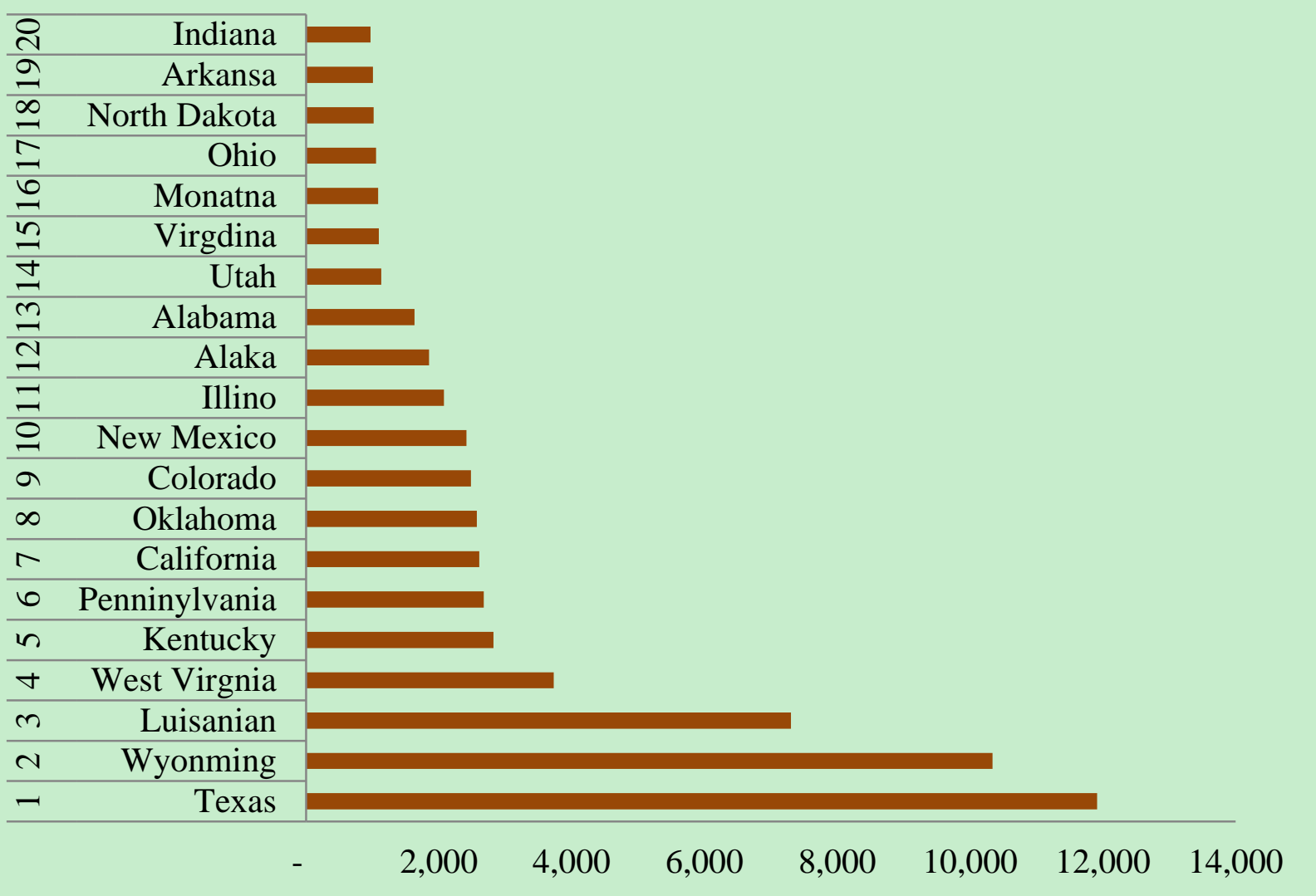

Figure 4. Ranking of production by US oil states

\section{Results}

The suitable linear equation of the crude oil price per barrel is modeled using equation (1) and the predicted coefficients were unbiased and consistent. However they are not efficient due in part that the data were time-series. Additional factor that influences the crude oil price per barrel is the Louisiana gas price. The higher the gas prices in Louisiana, the higher the crude oil price per barrel as if the oil and gas industry increase the crude production in Louisiana. Such high gas price in Louisiana tends to adjust the crude oil price per barrel thus increasing drilling and well development in Louisiana.

Table 2. Multivariate Correlation Matrix

\begin{tabular}{llll} 
Louisiana & Louisiana Median & Unemployment & Crude Oil Price \\
Gas Price & Household Income & Por Barrel \\
& & Louisiana & \\
\hline
\end{tabular}

Louisiana

Gas Price

Louisiana Median

Household Income $\quad 0.3476^{*}$

Unemployment

$\begin{array}{lll}\text { Rate in } & 0.0183 * & 0.0659 *\end{array}$ 
Louisiana

Crude Oil Price

$\begin{array}{lll}\text { Per Barrel 0.9530* } & 0.3398 * & 0898 *\end{array}$

Note. ${ }^{*} p$-value $<0.05$.

From Table 2, the multivariate correlation matrix shows that some variables are significant at $p$ - value of 0.05 . The largest values indicated that the crude oil price per barrel was strongly positive $(r=0.9530)$ linked with Louisiana gas price while Louisiana median household income $(r=0.0898)$, unemployment rate in Louisiana $(r=0.3398)$. The variables in the multivariate correlation matrix that were significant were included in general regression model where the dependent variable was the crude oil price per barrel. In Tables 3, regression coefficients crude oil price per barrel variable are positive which displays that as gas price; crude oil price per barrel also increase in Louisiana. The crude oil price per barrel coefficient is positive when Louisiana median household income. Also, the crude oil price per barrel coefficient is positive when unemployment rate in Louisiana.

Table 3. Regression estimated parameter of crude oil price variable for Louisiana Component, 2000-2020

\begin{tabular}{|c|c|c|c|c|}
\hline & Coefficients & Standard Error & t Stat & P-value \\
\hline Intercept & -20.4837 & 15.8722 & -1.2905 & 0.2141 \\
\hline \multicolumn{5}{|l|}{ Louisiana } \\
\hline Gas Price & 29.7523 & 2.3849 & 12.4780 & 0.0000 \\
\hline \multicolumn{5}{|l|}{ Louisiana Median } \\
\hline Household Income & 0.0023 & 0.0004 & 0.0645 & 0.0949 \\
\hline \multicolumn{5}{|l|}{ Unemployment } \\
\hline \multicolumn{5}{|l|}{ Rate in } \\
\hline Louisiana & 1.5107 & 1.5007 & 1.0067 & 0.0382 \\
\hline
\end{tabular}

Table 4 specifies regression estimated parameter of crude oil price variable for Louisiana component, 2000-2020 by the model resulted in all variables are statistically significant at the $p$-value 0.05 level namely Louisiana gas price, Louisiana median household income, and unemployment rate in Louisiana with $R^{2}=95.57 \%$.

Table 4. Regression statistics

\begin{tabular}{lr}
\hline Multiple R & 0.955709 \\
R Square & 0.91338 \\
Adjusted R Square & 0.898094 \\
Standard Error & 8.410459 \\
\hline
\end{tabular}


Table 5. ANOVA

\begin{tabular}{llllll}
\hline & df & SS & MS & F & Significance F \\
\hline Regression & 3 & 12680.11 & 4226.704 & 59.75338 & $3.07 \mathrm{E}-09$ \\
Residual & 17 & 1202.509 & 70.73582 & & \\
Total & 20 & 13882.62 & & & \\
\hline
\end{tabular}

\section{Conclusion}

This current research measures the impact of Louisiana gas price, Louisiana median household income, and unemployment rate in Louisiana on the crude oil in Louisiana to examine the cause of distortions in the oil and gas market in Louisiana. The results indicate that Louisiana median household income, and unemployment rate in Louisiana are the crucial components for fluctuations in crude oil in Louisiana. Furthermore, other contributing factors such gas prices and crude demand from China, India, and Brazil are also usual trend as established by urban macroeconomic trade that often impact of local market like Louisiana gas price. However, one key feature of this research is the role of local unemployment rate in Louisiana.

The result shows that a high unemployment rate in Louisiana lowers the Louisiana gas price and therefore inhibits oil and gas market. The regression analysis showed that unemployment rate in Louisiana to rise with the Louisiana gas price; this has been the result of fluctuations in central determinants in the Louisiana economy as whole. In addition, it is highly recommended that the U.S. could continue to increase drilling activities in the state of Louisiana all it wants but it is hard to expect greater domestic production to move gas prices by more than two percentage points in the next few years. The problem is that the market for oil is global and U.S. supply is relatively too small to make an impact.

\section{References}

American Community Survey 1-Year Estimates (B19013); Bureau of Labor Statistics, CPI-U-RS.

Department of Natural Resources. Retrieved from www.dnr.louisiana.gov

Retrieved December 4,2020, from https://fred.stlouisfed.org/series/MEHOINUSLAA646N

Retrieved from GasBuddy.com

Statistics for Business and Economics; Anderson, Sweeney, Williams (textbook).

U.S. Census Bureau, Median Household Income in Louisiana [MEHOINUSLAA646N], retrieved from FRED, Federal Reserve Bank of St. Louis

U.S. Census Bureau: Current Population Survey (CPS) - www.census.gov WTRG Economics - www.wtrg.com

\section{Copyrights}

Copyright for this article is retained by the author(s), with first publication rights granted to the journal.

This is an open-access article distributed under the terms and conditions of the Creative Commons Attribution license (http://creativecommons.org/licenses/by/4.0/). 